\title{
Use of 3D prototyping in congenital cardiovascular diseases - initial experience in Hong Kong
}

Janice J I ${ }^{1 *}$, Peter K Hui ${ }^{2}$, Robin Chen ${ }^{3}$, Eddie Wu ${ }^{4}, \mathrm{KH} \mathrm{Lau}{ }^{4}$, Stephen Cheung ${ }^{1}, \mathrm{TC}$ Yung ${ }^{3}$, Wendy W Lam ${ }^{1}$

From 18th Annual SCMR Scientific Sessions

Nice, France. 4-7 February 2015

\section{Background}

The use of 3D prototyping in medical practice is becoming increasingly important, due to the development of $3 \mathrm{D}$ printing and the recent rapid advances in relevant techniques and equipments. The use of 3D model is especially important in the field of paediatric cardiology and congenital cardiovascular disease, where there is a clear advantage over conventional 2D images in demonstrating complex anatomies and relationships between different structures.

\section{Methods}

The authors have selected a few paediatric cardiovascular diseases, and hope to share their initial experiences in $3 \mathrm{D}$ prototyping in this presentation.

\section{Results}

Different cases are included to illustrate the use of 3D prototyping in management of congenital cardiovasclar diseases.

\section{Conclusions}

The departments of radiology and paediatrics of a local teaching hospital and the department of medical engineering of a local university have started the first collaboration in Hong Kong, which pioneered the use of 3D printing in paediatric cardiovascular diseases.

\section{Authors' details}

'Department of Radiology, Queen Mary Hospital, Hong Kong, China.

${ }^{2}$ Radiology Department, Baptist Hospital, Hong Kong, China. ${ }^{3}$ Department of
A

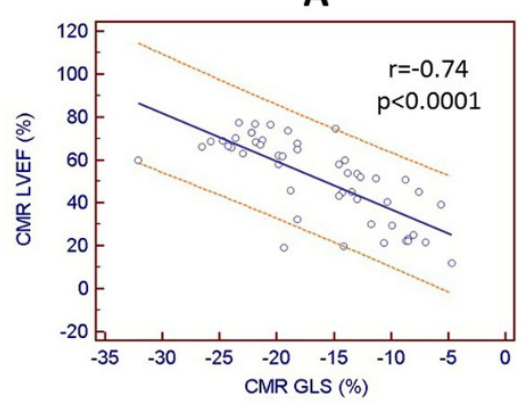

B

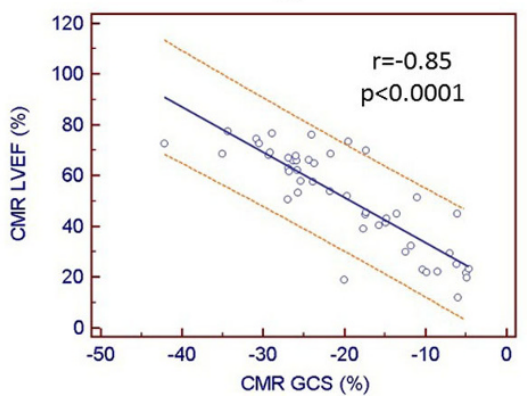

Figure 1

${ }^{1}$ Department of Radiology, Queen Mary Hospital, Hong Kong, China

Full list of author information is available at the end of the article 
Pediatrics-Cardiology, Queen Mary Hospital, Hong Kong, China. ${ }^{4}$ Department of Industrial and Systems Engineering, Hong Kong Polytechnic University, Hong Kong, China.

Published: 3 February 2015

doi:10.1186/1532-429X-17-S1-P225

Cite this article as: Ip et al:: Use of 3D prototyping in congenital cardiovascular diseases - initial experience in Hong Kong. Journal of Cardiovascular Magnetic Resonance 2015 17(Suppl 1):P225.

Submit your next manuscript to BioMed Central and take full advantage of:

- Convenient online submission

- Thorough peer review

- No space constraints or color figure charges

- Immediate publication on acceptance

- Inclusion in PubMed, CAS, Scopus and Google Scholar

- Research which is freely available for redistribution

Submit your manuscript at www.biomedcentral.com/submit 